THE EUROPEAN JOURNAL OF LIFE WRITING VOLUME VI(2017)R6-R9

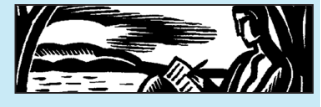

The Diary of Heinrich Witt. Edited by Ulrich Mücke, 10 volumes, Brill: Leiden, Boston 2016. (ISBN: 978-90-04-30726-1). Also available as e-book (ISBN 978-90-04-30724-7).

\title{
Angelika Schaser
}

Hamburg

A biography of Heinrich Witt authored by Christa Wetzel opens an impressive edition of Witt's diary, written during the nineteenth century. Heinrich Witt, born in 1799 in Altona into a Protestant merchant family, emigrated in his twenties to Peru where he spent most of his life until his death in 1892. After school, the young Witt started a career as a merchant in Altona and was sent to England by his father in 1823, he then left Europe to travel to Peru in 1824. First he acted for a trading company in London which started a new branch in Arequipa, Peru. In 1842 he went into business for himself, and initially dealt with wool and textiles, and then focused on financial business from the 1860s onwards. He held shares of the Pacific Steam Navigation Company and invested in banks, railway companies and an insurance company. In 1842 he was already so wealthy that he was able to live on the interest his investments generated. In April 1841, Witt had been accepted by the Peruvian government as the Kingdom of Denmark's first Consul. This intermediary function between Europe and Peru was so important for Witt that in 1844 he tried to also become the Swedish and the Norwegian Consul in Lima. These attempts failed. However, after his resignation Witt managed to pass the position of the Danish Consul in Lima to his grandson Enrique Garland, who was appointed Denmark's General Consul in 1877. When Enrique Garland died in 1884, Witt successfully supported Geraldo, Enrique's brother, to become the new Danish Consul General in Peru. Witt's rise into the upper class of Lima, where he lived from 1833, succeeded with the marriage to the twice-widowed María Sierra Velarde, a member of a distinguished Peruvian family. She brought three children into their marriage. After his wife's death in 1876, Witt retired from business and lived from then on as pensioner in Lima. He suffered significant financial loss during Peru's economic and political crisis in the 1870s, and when Lima was occupied by Chilean troops in 1881. 
Witt kept a diary regularly from 1820. He switched from German to English, firstly to improve his language skills for his employment in the British company Antony Gibbs and Sons. At the age of sixty, Witt began revising his diary. He wanted to pass on to his descendants the history of his rise from being a German merchant's son to someone who had made his fortune in South America and organized his life as a successful, respectable businessman. The history of his life, which he wrote down in thirteen revised volumes with over 11,000 pages, is nearly completely preserved. The thirteen volumes were transliterated, annotated, and edited by Ulrich Mücke and his team at Universität Hamburg, in a project lasting several years.

Now a unique source exists for research. As far as is known, this is the most extensive self-narrative from South America. Heinrich Witt who translated his German passages into English for the revised version of the diary, gives an account of his life as a wealthy businessman in Peru, of his travels in South America, and of his five extended journeys to Europe. Witt organized his travels as bourgeois "grand tours". He prepared himself with extensive reading and language courses, he used his trips not only to see old friends and family members, but for his own education, for the consolidation of his knowledge of these countries and to initiate or maintain business contacts all over the world. Often he traveled to Europe with his wife and other family members. Grandchildren, who were educated to some extent by Witt himself in Lima, nephews and nieces often were sent to Europe to attend school or to work in companies he had befriended. Witt sometimes accompanied them on their journeys to Europe or back to South America. Thus Witt became the center of a transnational, growing family, a form of a upper class dynasty of the commercial South American and European world. In his diary, Witt consistently refers to the significance of his contacts and his reputation for the business successes and societal standing of his family. Witt also commentated in his diary on political and economic events and developments, e.g., the revolution 1848/49 in Europe, trade between Europe and Latin America, the battle for Peru's independence, and the founding of the German Empire. The writing or rather the dictating and the revising of his diaries became a constant habit until the end of his life. Christa Wetzel characterized this activity as a "lifelong process of self-disciplining and also self-constituting". ${ }^{1}$

\footnotetext{
${ }^{1}$ Christa Wetzel: Schreibend leben. Heinrich Witt (1799-1892) und sein Tagebuch im Lima des 19. Jahrhunderts, in: Claudia Ulbrich/Hans Medick/Angelika Schaser (eds.), Selbstzeugnis und Person. Transkulturelle Perspektiven. Böhlau Verlag: Cologne, Weimar, Vienna 2012, p. 139-154, quotation p. 154.
} 
The diary which is now published in print and as an e-book, includes an index of persons and places (vol. X, p. 397-699), covering the names of more than 15,000 persons and places and over 1000 references. The elaborated transcription of the diary is supplemented by a biography of Witt, a history of his diary, an article which puts Witt's diary into the context of autobiographical writing in the nineteenth century, an analysis of the form and content of the diary, and a table indicating which parts of Witt's diary were translated into Spanish and published in 1987 and 1992, some remarks about the current edition, some pictures of Witt and his family (vol. 1, p. X-CLXXXIV), and a couple of facsimiles. This edition supports the detailed study of the implementation of the diary, the writing situation, Witt's motivation and intentions in keeping this diary, on which he reflected and kept writing about. Witt's diary can be analyzed systematically with respect to various issues, e.g., the Witt's everyday life is described in extenso in his familial relations and his transnational communicative contexts. As far as we know, Witt's everyday life with his bourgois European interests and habits differed strongly from the life of the small upper class in Lima. The universal educational claims, the learning targets and the self-imposed reading workload of this transcultural pater familiae were ambitious. The polyglot Witt considered European culture superior to all the others. Only his sense of responsibility towards his family made him stay in Lima, even though life in Europe seemed so much more attractive to him. The multiple relationships of the self become apparent in the numerous, entangled local, national, and transnational references of Witt's person and the different topics which are addressed in the diary. So the network of Peru's elite can be identified on the basis of Witt's detailed description of social and business relationships; Witt's perception of the gender and social hierarchies in South America and in Europe can be analyzed; his acting and thinking in familial relations; his ideas of national identity, progress and backwardness; honest and unfair business practices, to mention just a few themes.

Because of Witt's habit of following international political and economic developments and his continuing efforts to receive up-to-date information, there is almost no issue which is not addressed in this diary. To give an example, Witt discussed the significance of religion in history. Although he probably converted to Catholicism on the occasion of his marriage in 1831, he occasionally attended the Catholic mass in Lima after his wife's death, and visited Lourdes on his last trip to Europe with his daughters, he extensively described the Protestant reformation in Germany and the importance of the Protestant ethic for the North German merchants. From the passages concerning Witt's eye complaints, the reader not only learns about Witt's state of health, but also learns 
about the evolution of ophthalmology in Peru and in Europe, as Witt described diagnoses and treatments in detail in his diary.

In this diary, supported by the index of persons and places, one can also study the worldwide political development and the transnational networks of British, German and South American trade, as seen by Witt. Also, the strategies of well-known companies become apparent, which intensified trade with South America in the nineteenth century after the breakdown of Spanish colonial rule. And you can see Peru's involvement in the global slave trade, which is also represented in the microcosm of Witt's household. Witt employed Afro-Peruvian and Chinese domestic workers. Witt liked little children, the kitchen and his horses to be taken care of by Afro-Peruvian and Chinese staff. By contrast, the children's teachers as well as his secretaries and butlers usually came from Europe. Also the diary exemplifies the White man's arrogance as regards Blacks, indigenous people, and Asians.

This edition of Witt's diary constitutes a very important source for historians. It is also a treasure trove for interdisciplinary postcolonial and transcultural research. Literary scholars can identify Witt's narratological features and rhetorical strategies in detail. Witt's diary provides unique opportunities for a host of profound and innovative studies. 